\title{
DETERMINATION OF THE LOAD-BEARING CAPACITY FOR DRILLING PILES CONSIDERING THE COEFFICIENT OF THE SOIL POROSITY
}

\author{
${ }^{1}$ Vinnytsia National Technical University, Vinnytsia \\ ${ }^{2}$ Vinnytsia Scientific Research Forensic Center of the Ministry of Internal Affairs of Ukraine
}

The influence of the coefficient of porosity of sandy soils on the bearing capacity of drilling piles according to the results of their static tests in field conditions is analyzed. Piles of different lengths were tested. The pile lengths are in the range of 2 to $12.0 \mathrm{~m}$. The diameter of the pile trunk is in the range of $0.4 \mathrm{~m}$ to $0.83 \mathrm{~m}$. The load, which can be sustained by a specific drilling pile, was determined when the settling limit $s=40 \mathrm{~mm}$. It is established that the method of determining the bearing capacity adopted in the applicable standards corresponds to sandy soils with a high porosity coefficient, therefore, at low porosity coefficients, the real bearing capacity exceeds the one determined by the standards.

A table is proposed to determine the specific soil resistance on the lateral surface of the pile, taking into account the porosity coefficient. To solve this problem, we used the geotechnical software complex "Plaxis 3D Foundation", which simulated the stress-strain state of the drill pile in sands of different size and density. 14 types of sandy soils were modeled with a change in the porosity ratio from 0.45 to 0.75 .

The results of the calculations using the proposed table are compared with the results of static testing of drilling piles. The results showed better compliance with the test data compared to the norm methodology.

Keywords: pile, void ratio, mode of deformation, numerical simulation.

\section{The common target setting and its connection with important practical tasks}

In combination with the development of sites which are not very convenient for new constructions as well as sites with already existing buildings and constructions, which do not allow the dynamic influence, there are some tendencies to increase the use of drilling piles. The significant reserve to increase the efficiency of drilling piles is the improving of methods to determine their load-bearing capacity at the blue - print stage.

The analysis of the latest research and scientific papers. According to the gathered experience of drilling pile[ tests in Ukraine as well as abroad there is some evidence that the load-bearing capacity of the drilling piles, which is calculated with equations and database tables [1], is sometimes 2-3 times lower than the real load-bearing capacity, which is determined during the statics research. Consequently, the methods of determination of the load-bearing capacity for drilling piles need to be improved.

The parts of the common problem, which were earlier not solved, are segregated and described in this article. The existing code documents do not take into account the change of the load-bearing capacity depending of sand soil porosity [1]. The analysis of the research data proves the existence of such dependence [2]. The acceptance of the influence of sand soil porosity permits to use larger loads on the soils with low voids ratio and as a result to achieve economic benefits.

The purpose of the article. The purpose of the article is to determine the influence of the void ratio on the load-bearing capacity of the drilled piles in sand soils.

\section{The main subject of the article}

To solve the given task the results of statics testing of the drilled piles done at the Research Institute of Construction Work Execution and the Research Institute of Structural Engineering in Kyiv were used. The results of site testing of 15 drilled borings from 10 different sites were considered. The testing sites are located in following cities: Kyiv, Brovary and Boryspil. The sites had different soil conditions. The completely in sand soil submerged piles were chosen. 
The piles of different length were tested. The range of length is from 2 to $12.0 \mathrm{~m}$. The width of pile shafts is in the range from 0.4 to $0.83 \mathrm{~m}$. The load, which the given pile can bear, was determined after reaching the settlement limit $\mathrm{s}=40 \mathrm{~mm}$.

Fig. 1 shows the results of comparison for the load-bearing capacity for the drilling piles, determined according to the methods of code documents [1] with the use of data based table H.2.2 and the loadbearing capacity according to the results of the field tests with the static load.

The load-bearing capacity of the pile F according to the results of statics research is shown in the horizontal axis of the given diagram. The load-bearing capacity of the pile F1 calculated according to the existing code documents is shown in the vertical axis of the diagram. The diagonal solid graph corresponds to the optimum compliance of calculation and testing results.

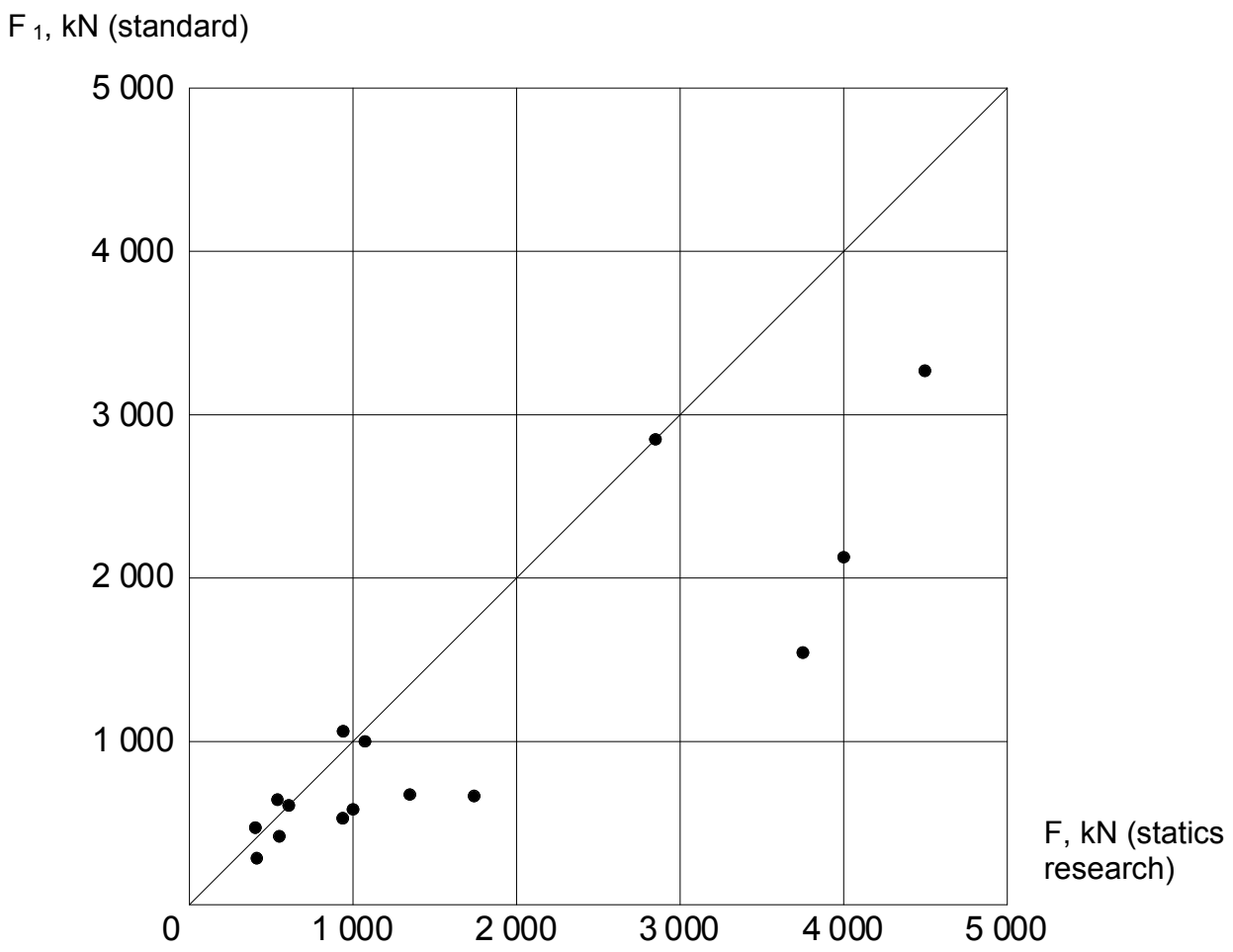

Fig. 1 - Diagram of load-bearing capacity of drilling piles in sand soils determined according to the methods of code documents [1] and load-bearing capacity according to the results of statics research

The results of calculation and statics testing coincided in four cases ( $27 \%$ of all considered cases). The reserve coefficient $(\mathrm{F} / \mathrm{F})$ of the load-bearing capacity in comparison to the code document calculation makes to 1.97. The analysis of the obtained reserve coefficients shows, that there is a direct dependence of their value from the sand void ratio. The reserve is large at low coefficients, at high coefficients the reserve is low or absent.

The geotechnical software "Plaxis 3D Foundation" was used to solve the given task. With the help of this software, the stress strain behavior of the drilling pile in sands of different specific gravity and grading was simulated. The model of the soil base is the compressed-tensile model of Mohr-Coulomb. Such model of the soil permits to simulate the pile work under the load with satisfactory accuracy. The obtained value is compared with the values of the field research [3]. Sandy soils of 14 kinds with following physics-mathematics characteristics were used for simulation:

1) coarse sands e $=0.55 ; \mathrm{c}_{\mathrm{I}}=2 \mathrm{kPa} ; \varphi_{\mathrm{I}}=43^{\circ} ; \mathrm{E}=50 \mathrm{MPa}$;

2) coarse sands $\mathrm{e}=0.55 ; \mathrm{c}_{\mathrm{I}}=1 \mathrm{kPa} ; \varphi_{\mathrm{I}}=40^{\circ} ; \mathrm{E}=40 \mathrm{MPa}$;

3) coarse sands e $=0.65 ; \mathrm{c}_{\mathrm{I}}=0 \mathrm{kPa} ; \varphi_{\mathrm{I}}=38^{\circ} ; \mathrm{E}=30 \mathrm{MPa}$;

4) concrete sands e $=0.45 ; \mathrm{c}_{\mathrm{I}}=3 \mathrm{kPa} ; \varphi_{\mathrm{I}}=40^{\circ} ; \mathrm{E}=50 \mathrm{MPa}$;

5) concrete sands e $=0.55 ; \mathrm{c}_{\mathrm{I}}=2 \mathrm{kPa} ; \varphi_{\mathrm{I}}=38^{\circ} ; \mathrm{E}=40 \mathrm{MPa}$;

6) concrete sands e $=0.65 ; \mathrm{c}_{\mathrm{I}}=1 \mathrm{kPa} ; \varphi_{\mathrm{I}}=35^{\circ} ; \mathrm{E}=30 \mathrm{MPa}$;

7) fine sands $\mathrm{e}=0.45 ; \mathrm{c}_{\mathrm{I}}=6 \mathrm{kPa} ; \varphi_{\mathrm{I}}=38^{\circ} ; \mathrm{E}=48 \mathrm{MPa}$;

8) fine sands $\mathrm{e}=0.55 ; \mathrm{c}_{\mathrm{I}}=4 \mathrm{kPa} ; \varphi_{\mathrm{I}}=36^{\circ} ; \mathrm{E}=38 \mathrm{MPa}$;

9) fine sands $\mathrm{e}=0.65 ; \mathrm{c}_{\mathrm{I}}=2 \mathrm{kPa} ; \varphi_{\mathrm{I}}=32^{\circ} ; \mathrm{E}=28 \mathrm{MPa}$; 
10) fine sands $\mathrm{e}=0.75 ; \mathrm{c}_{\mathrm{I}}=0 \mathrm{kPa} ; \varphi_{\mathrm{I}}=28^{\circ} ; \mathrm{E}=18 \mathrm{MPa}$;

11) loose sands $\mathrm{e}=0.45 ; \mathrm{c}_{\mathrm{I}}=8 \mathrm{kPa} ; \varphi_{\mathrm{I}}=36^{\circ} ; \mathrm{E}=39 \mathrm{MPa}$;

12) loose sands e $=0.55 ; \mathrm{c}_{\mathrm{I}}=6 \mathrm{kPa} ; \varphi_{\mathrm{I}}=34^{\circ} ; \mathrm{E}=28 \mathrm{MPa}$;

13) loose sands e $=0.65 ; \mathrm{c}_{\mathrm{I}}=4 \mathrm{kPa} ; \varphi_{\mathrm{I}}=30^{\circ} ; \mathrm{E}=18 \mathrm{MPa}$;

14) loose sands $\mathrm{e}=0.75 ; \mathrm{c}_{\mathrm{I}}=2 \mathrm{kPa} ; \varphi_{\mathrm{I}}=26^{\circ} ; \mathrm{E}=11 \mathrm{MPa}$.

The load-bearing capacity of the drilling pile with the diameter of $0.5 \mathrm{~m}$ and the length of $10 \mathrm{~m}$ was determined at the total strain of $4 \mathrm{~cm}$.

Table 1 gives the results of the calculations for the load-bearing capacity of the pile for the determined soils using the methods, the proposed codes [1], and according to the results of numerical modeling with "Plaxis 3D Foundation". When determining the load-bearing capacity according to the code documents the resistance under the lower pile edges was calculated with the formula (H.3.2), taking into account the internal friction angle and specific weigh of the soil. The side friction was calculated either with the schedule H.2.2 or with the formula (H.2.2) (as the function of strength characteristic).

The results obtained with the numeric modeling have shown that the load-bearing capacity of the drilling pile decreases $1.5-2$ times when the voids ratio increases.

As long as the strength properties depend on voids ratio, the with the code documents determined load-bearing capacity has the indirect dependence on soil density. When using the lateral resistance calculated with the formula (H.2.2), this dependence equals to the dependence received with the numeric modeling. When using the lateral resistance, determined with the schedule H.2.2, this dependence is far more less, because only the resistance under the pile lower edge dictates it.

The disadvantage of the formula (H.2.2) used to determine the lateral resistance is the lower total loadbearing capacity (it is lower than the load-bearing capacity determined with the help of the schedule H.2.2, which in turn is less than the results of the field research shown in the Fig.1).

That means that the schedule equal to H.2.2 can be used with considering the influence of the voids ratio.

Table 1

The comparison of the load-bearing capacity of the drilling pile, determined according to the code documents and with the numeric modeling "Plaxis 3D Foundation"

\begin{tabular}{|c|c|c|c|c|c|c|c|c|}
\hline \multirow[b]{2}{*}{ Soils } & \multicolumn{4}{|c|}{$\begin{array}{c}\text { Physical-mechanical } \\
\text { characteristics } \\
\text { of soils }\end{array}$} & \multicolumn{4}{|c|}{ Load-bearing capacity of the pile } \\
\hline & $\mathrm{e}$ & $\mathrm{c}, \mathrm{kPa}$ & $\varphi,^{\circ}$ & $\mathrm{E}, \mathrm{mPa}$ & 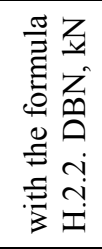 & 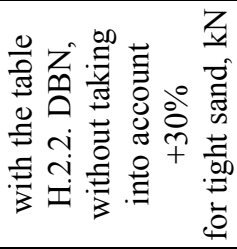 & 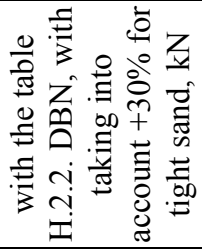 & 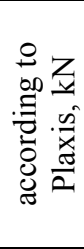 \\
\hline 1 & 2 & 3 & 4 & 5 & 6 & 7 & 8 & 9 \\
\hline \multirow{3}{*}{ Coarse sands } & 0.45 & 2 & 43 & 50 & 1498.3 & 1736.7 & 1909.8 & 1740 \\
\hline & 0.55 & 1 & 40 & 40 & 1463.1 & 1736.7 & 1736.7 & 1393 \\
\hline & 0.65 & 0 & 38 & 30 & 1103.3 & 1405.5 & 1405.5 & 1095 \\
\hline \multirow{3}{*}{ Concrete sands } & 0.45 & 3 & 40 & 50 & 1476.3 & 1736.7 & 1909.8 & 1651 \\
\hline & 0.55 & 2 & 38 & 40 & 1299.7 & 1590.9 & 1590.9 & 1282 \\
\hline & 0.65 & 1 & 35 & 30 & 868.3 & 1192.5 & 1192.5 & 989 \\
\hline \multirow{4}{*}{ Fine sands } & 0.45 & 6 & 38 & 48 & 1313.9 & 1404 & 1526.6 & 1503 \\
\hline & 0.55 & 4 & 36 & 38 & 925.9 & 1049 & 1171.6 & 1182 \\
\hline & 0.65 & 2 & 32 & 28 & 571.9 & 743.3 & 743.3 & 833 \\
\hline & 0.75 & - & 28 & 18 & 355.7 & 577.7 & 577.7 & 556 \\
\hline \multirow{4}{*}{ Loose sands } & 0.45 & 8 & 36 & 39 & 1014 & 995.3 & 1084 & 1301 \\
\hline & 0.55 & 6 & 34 & 28 & 761.8 & 773.8 & 862.5 & 968 \\
\hline & 0.65 & 4 & 30 & 18 & 510.7 & 533.8 & 533.8 & 665 \\
\hline & 0.75 & 2 & 26 & 11 & 339.3 & 443.7 & 443.7 & 481 \\
\hline
\end{tabular}


For the further voids ratio influence analysis the modeling results were processed in such a manner:

- The load on the lower edge of the pile and the lateral resistance were determined (the part of the lower edge was equal to the part calculated according to the code documents).

- Regularity accepted in the schedule H.2.2 [1] that takes into account the increasing factors for tight sands was used to determine the relative density for lateral resistance with different depths through the pile length.

As a consequence the table 2 with the values of the relative density in the lateral surface of the pile was received which is similar to the schedule H.2.2 but with the introducing of an additional increasing factors in the form of voids ratio. This schedule was made out for piles with the length $10 \mathrm{~m}$. The lateral resistance is determined by means of the rate from the values of the load-bearing capacity, received from the DBN schedule with taking into account $+30 \%$ for dense soils.

Table 2

Calculated soil resistivity on the lateral area of drilling piles

\begin{tabular}{|c|c|c|c|c|c|}
\hline \multirow{2}{*}{$\begin{array}{l}\text { Depth of the } \\
\text { layer, } m\end{array}$} & \multirow{2}{*}{ Voids ratio } & \multicolumn{4}{|c|}{ Calculated sand resistivity on the lateral area of drilling piles, $\mathrm{kPa}$} \\
\hline & & coarse sands & concrete sands & fine sands & loose sands \\
\hline 1 & 2 & 3 & 4 & 5 & 6 \\
\hline \multirow{4}{*}{1} & 0.45 & 44.7 & 41.5 & 33.4 & 30.1 \\
\hline & 0.55 & 24.6 & 24.8 & 34.6 & 27.3 \\
\hline & 0.65 & 23.4 & 26 & 27.5 & 21.6 \\
\hline & 0.75 & - & - & 21.6 & 17.3 \\
\hline \multirow{4}{*}{2} & 0.45 & 51.7 & 48.5 & 40.4 & 36.1 \\
\hline & 0.55 & 31.6 & 31.8 & 41.6 & 33.3 \\
\hline & 0.65 & 30.4 & 33 & 34.5 & 27.6 \\
\hline & 0.75 & - & - & 28.6 & 23.3 \\
\hline \multirow{4}{*}{3} & 0.45 & 57.7 & 54.5 & 45.4 & 40.1 \\
\hline & 0.55 & 37.6 & 37.8 & 46.6 & 37.3 \\
\hline & 0.65 & 36.4 & 39 & 39.5 & 31.6 \\
\hline & 0.75 & - & - & 33.6 & 27.3 \\
\hline \multirow{4}{*}{4} & 0.45 & 62.7 & 59.5 & 48.4 & 42.1 \\
\hline & 0.55 & 42.6 & 42.8 & 49.6 & 39.3 \\
\hline & 0.65 & 41.4 & 44 & 42.5 & 33.6 \\
\hline & 0.75 & - & - & 36.6 & 29.3 \\
\hline \multirow{4}{*}{5} & 0.45 & 65.7 & 62.5 & 50.4 & 44.1 \\
\hline & 0.55 & 45.6 & 45.8 & 51.6 & 41.3 \\
\hline & 0.65 & 44.4 & 47 & 44.5 & 35.6 \\
\hline & 0.75 & - & - & 38.6 & 31.3 \\
\hline \multirow{4}{*}{6} & 0.45 & 67.7 & 64.5 & 52.4 & 46.1 \\
\hline & 0.55 & 47.6 & 47.8 & 53.6 & 43.3 \\
\hline & 0.65 & 46.4 & 49 & 46.5 & 37.6 \\
\hline & 0.75 & - & - & 40.6 & 33.3 \\
\hline \multirow{4}{*}{7} & 0.45 & 69.7 & 66.5 & 53.4 & 47.1 \\
\hline & 0.55 & 49.6 & 49.8 & 54.6 & 44.3 \\
\hline & 0.65 & 48.4 & 51 & 47.5 & 38.6 \\
\hline & 0.75 & - & - & 41.6 & 34.3 \\
\hline \multirow{4}{*}{8} & 0.45 & 71.7 & 68.5 & 54.4 & 48.1 \\
\hline & 0.55 & 51.6 & 51.8 & 55.6 & 45.3 \\
\hline & 0.65 & 50.4 & 53 & 48.5 & 39.6 \\
\hline & 0.75 & - & - & 42.6 & 35.3 \\
\hline \multirow{4}{*}{9} & 0.45 & 73.2 & 70 & 55.4 & 48.6 \\
\hline & 0.55 & 53.1 & 53.3 & 56.6 & 45.8 \\
\hline & 0.65 & 51.9 & 54.5 & 49.5 & 40.1 \\
\hline & 0.75 & - & - & 43.6 & 35.8 \\
\hline \multirow{4}{*}{10} & 0.45 & 74.7 & 71.5 & 56.4 & 49.1 \\
\hline & 0.55 & 54.6 & 54.8 & 57.6 & 46.3 \\
\hline & 0.65 & 53.4 & 56 & 50.5 & 40.6 \\
\hline & 0.75 & - & - & 44.6 & 36.3 \\
\hline
\end{tabular}


The comparison of the load-bearing capacity of the drilling piles, determined according to the schedule 2 , with the research data and with the load-bearing capacity, determined according to the code documents

\begin{tabular}{|c|c|c|c|c|c|c|c|c|c|c|c|c|}
\hline \multirow{2}{*}{ № } & \multirow{2}{*}{ Name of facility } & \multirow{2}{*}{ 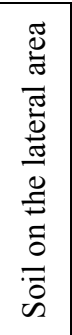 } & \multicolumn{2}{|c|}{$\begin{array}{l}\text { Size of the } \\
\text { drilling } \\
\text { pile }\end{array}$} & \multicolumn{4}{|c|}{$\begin{array}{c}\text { Physical-mechanical } \\
\text { properties of the soil on the } \\
\text { lateral area }\end{array}$} & \multirow{2}{*}{ 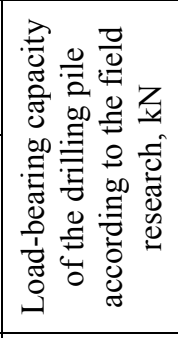 } & \multirow{2}{*}{ 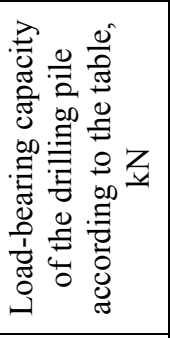 } & \multirow{2}{*}{ 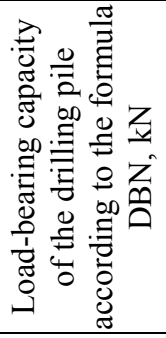 } & \multirow{2}{*}{ 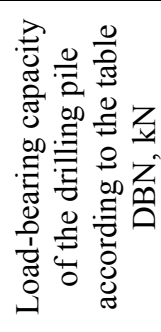 } \\
\hline & & & $\stackrel{\Xi}{\lrcorner}$ & $\begin{array}{l}\Xi \\
\text { ठீ }\end{array}$ & 0 & 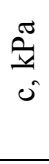 & $\hat{\theta}$ & 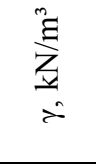 & & & & \\
\hline 1 & $\begin{array}{l}\text { Kyiv, NSC } \\
\text { Olympiyskiy } \\
\text { test drilling- } \\
\text { 1(TD), TD-5, } \\
\text { TD-6 }\end{array}$ & $\begin{array}{l}\tilde{y} \\
0 \\
\tilde{D} \\
0 \\
0 \\
0 \\
0\end{array}$ & 7.0 & 0.42 & 0.7 & 2 & 33 & 19.9 & $\begin{array}{c}(930+550+ \\
+500) / 3= \\
=660\end{array}$ & 536 & 474 & 514 \\
\hline 2 & $\begin{array}{c}\text { Boryspil TD-12 } \\
\text { (pile group 6) }\end{array}$ & 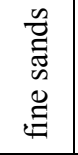 & 7.0 & 0.6 & 0.63 & 1 & 30 & 18.9 & 2475 & 912 & 811 & 890 \\
\hline 3 & $\begin{array}{l}\text { Kyiv, } \\
\text { Vyborhs'ka- } \\
\text { street, TD-1 } \\
\text { (№33) }\end{array}$ & 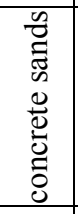 & 8.0 & 0.42 & 0.616 & 0 & 31 & 17.8 & 425 & 470 & 296 & 533 \\
\hline 4 & $\begin{array}{c}\text { Kyiv, } \\
\text { motorcycle } \\
\text { factory, building } \\
\text { №5 }\end{array}$ & 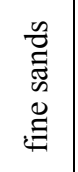 & 5.0 & 0.6 & $0.66-0.68$ & 0 & 37 & 17.9 & 1129 & 1024 & 890 & 997 \\
\hline 5 & $\begin{array}{c}\text { Kyiv, health } \\
\text { center №2, } \\
\text { Verhniaya street }\end{array}$ & $\begin{array}{l}\tilde{\theta} \\
\vec{E} \\
\ddot{D} \\
\ddot{\Xi}\end{array}$ & 10.76 & 0.66 & $\sim 0.65$ & & & $\sim 17.9$ & 2500 & 2200 & & 2164 \\
\hline 6 & $\begin{array}{l}\text { Kyiv, CHPP-5, } \\
\text { chimney neck } \\
\text { №1 }\end{array}$ & $\mid \begin{array}{ll}0 \\
0 \\
0 \\
0 & 0 \\
0 & 0 \\
0 & 0 \\
0 & 0\end{array}$ & 12,0 & 0.58 & $\sim 0.65$ & & & $\sim 17.8$ & 3000 & 2013 & & 2137 \\
\hline
\end{tabular}

The values of the load-bearing capacity were determined with the help of the table 2 for research sites. The research led to the deformation of $4 \mathrm{sm}$. The pile length equals $10 \mathrm{~m}$; the pile was completely immersed into the sandy soil. Table 3 shows the comparison of the experimental results with the results from the table 2. The resistance under the lower pile edge was determined according to the formula (H.3.2) (1). The results of the load-bearing capacity, determined according to the code documents, are shown in table 3.

The results better correspond to the research data in comparison with the results determined according to the code documents.

\section{Conclusions}

As the result of mathematical simulation, the schedule of the relative density for sandy soils on the lateral area of drilling piles was obtained with taking into account the soil porosity ratio for the piles with the length up to $10 \mathrm{~m}$. The use of this schedule helps to receive more economical solutions for the design.

\section{REFERENCES}

1. Basements and foundations of constructions: DBN B.2.1-10-2009 with the changes №1 and №2 - - (not valid before 2017-0701). Kyiv: Ministry of Regional Housing and Building in Ukraine, 2009. - 161 p. - (NS of Ukraine).

2. Maievska I. V., Blashchuk N. V., Romanov S. V. Improving of methods to determine the load-bearing capacity of drilling piles// "Engineering structures": Institutional collection of scientific and technical articles. - Issue 83. - K.: NRICC, 2016. p. 616-625. 
3. Taking into account the load distributing structure as a part of continuous pile foundations and strengthened pile foundations : Monograph / Maievska I. V., Blashchuk N. V. - Vinnytsia: VNTY, 2013. - 168 p.

Maievska Irina Victorivna - Ph.D., assistant professor of building, urban planning and architecture Vinnytsia National Technical University. ORCID: 0000-0001-9764-0271, e-mail: irina.mayevskaja@gmail.com.

Blashchuk Natalya Victorivna - Ph.D., assistant professor of building, urban planning and architecture Vinnytsia National Technical University. ORCID: 0000-0001-5999-6824, e-mail: vernatav@ukr.net.

Korchinsky Alexander - Forensic expert from the department of construction, land research's and evaluation activities of the Vinnytsia Scientific Research Forensic Center of the Ministry of Internal Affairs of Ukraine, e-mail: korchin_sky@i.ua.

\title{
I. В. Маєвська ${ }^{1}$ Н. В. Блащук ${ }^{1}$ О. А. Корчинський ${ }^{2}$ \\ ВИЗНАЧЕННЯ НЕСУЧОЇ ЗДАТНОСТІ БУРОВИХ ПАЛЬ З ВРАХУВАННЯМ КОЕФІЦЕНТУ ПОРИСТОСТІ ГРУНТІВ
}

\author{
${ }^{1}$ Вінницький національний технічний університет \\ ${ }^{2}$ Вінницький науково-дослідний експертно-криміналістичний центр
}

Проаналізований вплив коефіцієнту пористості піщаних грунтів на несучу здатність бурових паль за результатами їх статичних випробувань у польових умовах. Випробовувались палі різної довжини. Довжини паль знаходяться в діапазоні від 2 до 12,0 м. Діаметр ствола паль знаходиться в межах від 0,4 м до 0,83 м. Навантаження, яке може витримати конкретна бурова паля, визначалося при досягнені межі осідання $s=40$ мм. Встановлено, що прийнята в чинних нормах методика визначення несучої здатності відповідає піщаним грунтам з високим коефіцієнтом пористості, отже при низьких коефіцієнтах пористості реальна несуча здатність перевищує визначену за нормами.

Запропонована таблиця для визначення питомого опору грунту по боковій поверхні палі з врахуванням коефріцієнту пористості. Для розв'язання поставленої задачі використовувався геотехнічний програмний комплекс «Plaxis 3D Foundation», за допомогою якого моделювався напружено-дефрормований стан бурової палі в пісках різної крупності та щільності. Моделювалось 14 видів піщаних грунтів із зміненням коефріцієнту пористості від 0,45 до 0,75.

Результати розрахунків з використанням запропонованої таблиці порівняні з результатами статичних випробувань бурових паль. Результати показали кращу відповідність дослідним даним у порівнянні $з$ методикою норм.

Ключові слова: паля, коефріцієнт пористості, напружено-дефрормований стан, числове моделювання.

Маєвська Ірина Вікторівна - к. техн. наук, доцент кафедри будівництва, міського господарства та архітектури Вінницького національного технічного університету.

Блащук Наталя Вікторівна - к. техн. наук, доцент кафедри будівництва, міського господарства та архітектури Вінницького національного технічного університету.

Корчинський Олександр Анатолійович - судовий експерт відділу будівельних, земельних досліджень і оціночної діяльності Вінницького науково-дослідного експертно-криміналістичного центра МВД України.

\section{И. В. Маевская ${ }^{1}$ \\ Н. В. Блащук ${ }^{1}$ \\ А. А. Корчинский \\ ОПРЕДЕЛЕНИЕ НЕСУЩЕЙ СПОСОБНОСТИ БУРОВЫХ СВАЙ С УЧЕТОМ КОЭФФИЦИЕНТА ПОРИСТОСТИ ГРУНТОВ}

\author{
${ }^{1}$ Винницкий национальный технический университет \\ ${ }^{2}$ Винницкий научно-исследовательский экспертно-криминалистический центр
}

\begin{abstract}
Проанализировано влияние коэффрициента пористости песчаных грунтов на несущую способность буровых свай по результатам их статических испытаний в полевых условиях. Испытывались сваи разной длины. Длины свай находятся в диапазоне от 2 до 12,0 м. Диаметр ствола свай находится в пределах от 0,4 м до 0,83 м. Нагрузка, которую может выдержать конкретная буровая свая, определялась при достижении предельной осадки $s=40$ мм. Установлено, что принятая в действующих нормах методика определения несущей способности отвечает песчаным грунтам с высоким коэффициентом пористости, таким образом, при низких коэффрициентах пористости реальная несущая способность превышает определенную по нормам.
\end{abstract}


Предложена таблица для определения удельного сопротивления грунта по боковой поверхности сваи с учетом коэффициента пористости. Для решения поставленной задачи использовался геотехнический программный комплекс «Plaxis 3D Foundation», c помощью которого моделировалось напряженнодеформированное состояние буровой сваи в песках разной крупности и плотности. Моделировалось 14 видов песчаных грунтов с изменением коэфрфициента пористости от 0,45 до 0,75.

Результаты расчетов с использованием предложенной таблицы сравнивались с результатами статических испытаний буровых свай. Результаты показали лучшее соответствие опытным данным по сравнению с методикой норм.

Ключевые слова: свая, коэффрициент пористости, напряженно-деформированное состояние, Численное моделирование.

Маевская Ирина Викторовна - к.т.н., доцент кафедры строительства, городского хозяйства и архитектуры Винницкого национального технического университета.

Блацук Наталья Викторовна - к.т.н., доцент кафедры строительства, городского хозяйства и архитектуры Винницкого национального технического университета.

Корчинский Александр Анатольевич - судебный эксперт отдела строительных, земельных исследований и оценочной деятельности Винницкого научно-исследовательского экспертно-криминалистического центра МВД Украины. 